IZA DP No. 9153

Labor Supply and Productivity Responses to Non-Salary Benefits: Do They Work? If So, at What Level Do They Work Best?

Marilyn Spencer

Deniz Gevrek

Valrie Chambers

Randall Bowden

June 2015 


\title{
Labor Supply and Productivity Responses to Non-Salary Benefits: Do They Work? If So, at What Level Do They Work Best?
}

\author{
Marilyn Spencer \\ Texas A\&M University-Corpus Christi \\ Deniz Gevrek \\ Texas A\&M University-Corpus Christi and IZA \\ Valrie Chambers \\ Stetson University \\ Randall Bowden \\ Texas A\&M University-Corpus Christi
}

Discussion Paper No. 9153

June 2015

IZA

P.O. Box 7240

53072 Bonn

Germany

Phone: +49-228-3894-0

Fax: +49-228-3894-180

E-mail: iza@iza.org

Any opinions expressed here are those of the author(s) and not those of IZA. Research published in this series may include views on policy, but the institute itself takes no institutional policy positions. The IZA research network is committed to the IZA Guiding Principles of Research Integrity.

The Institute for the Study of Labor (IZA) in Bonn is a local and virtual international research center and a place of communication between science, politics and business. IZA is an independent nonprofit organization supported by Deutsche Post Foundation. The center is associated with the University of Bonn and offers a stimulating research environment through its international network, workshops and conferences, data service, project support, research visits and doctoral program. IZA engages in (i) original and internationally competitive research in all fields of labor economics, (ii) development of policy concepts, and (iii) dissemination of research results and concepts to the interested public.

IZA Discussion Papers often represent preliminary work and are circulated to encourage discussion. Citation of such a paper should account for its provisional character. A revised version may be available directly from the author. 


\begin{abstract}

\section{Labor Supply and Productivity Responses to Non-Salary Benefits:} Do They Work? If So, at What Level Do They Work Best?*

This study explores the impact of a particular low marginal-cost employee benefit on employees' intended retention and performance. By utilizing a unique data set constructed by surveying full-time faculty and staff members at a public university in the United States, we study the impact of this employee benefit on faculty and staff performance and retention. We focus on the impact of reduction in dependent college tuition at various levels on employees' intentions to work harder and stay at their current job by using both OLS and Ordered Probit models. We also simulate the direct opportunity cost (reduction in revenue) in dollars and as a percent of total budgeted revenue to facilitate administrative decision making. The results provide evidence that for institutions where employee retention and productivity are a priority, maximizing or offering dependent college tuition waiver may be a relatively low-cost benefit to increase intended retention and productivity. In addition, the amount of the tuition waiver, number of dependents and annual salary are statistically significant predictors of intended increased productivity and intent to stay employed at the current institution. Employee retention and productivity is a challenge for all organizations. Although pay, benefits, and organizational culture tend to be key indicators of job satisfaction, little attention is given to specific types of benefits. This study is the first comprehensive attempt to explore the relationship between the impact of this low-cost employee benefit and employee performance and retention in a higher education institution in the United States.
\end{abstract}

JEL Classification: J22, J32, J45, M52

Keywords: $\quad$ higher education, retention, employee satisfaction, productivity, job satisfaction, fringe benefits

Corresponding author:

Deniz Gevrek

Texas A\&M University-Corpus Christi

6300 Ocean Drive, Unit 5808

Corpus Christi, TX 78412

USA

E-mail: deniz.gevrek@tamucc.edu

\footnotetext{
${ }^{*}$ The authors gratefully acknowledge the support of Texas A\&M University-Corpus Christi.
} 


\section{Introduction}

Employee retention and productivity is a challenge for organizations of all types. The cost of losing employees and recruiting replacements averages approximately 20\% (Boushey and Glynn, 2012) and often exceeds 100\% of annual compensation for each position lost (Bryant \& Allen, 2013). Tillman (2013) advised that one way to mitigate employee turnover was for an organization to offer robust benefits. According to Tillman (2013), those who work for organizations that offer benefits with which employees are extremely satisfied or very satisfied are six times more likely to stay with their current employers than those who are dissatisfied with benefits. Colleges and universities are in a unique position. With the cost of a college education outpacing even medical care expenses and the overall consumer price indices (Slaper \& Foston, 2013), postsecondary institutions could offer its employees reduced tuition rates as a low- or noadditional cost benefit of employment. What effect would this have on employee retention and productivity?

Although managing retention and productivity can be successful, according to Bryant and Allen (2013), efforts are often based on leadership’s "gut instinct” rather than empirical research. This study examines what effects the benefit of reduced tuition for faculty and staff dependents might have toward employee retention and productivity at a public university in the United States. Employee turnover is expensive for businesses of all types. Boushey and Glynn (2012) examined 30 case studies from 1992 to 2007 and they estimated that the average replacement cost to the employer as approximately $20 \%$ of that employee's annual salary. The higher the skill set of the employee, the higher the cost to the company. They found that some policies can help to reduce employee turnover, including family-friendly policies that give workers the flexibility to balance work and family (Boushey and Glynn, 2012). 
At the public university studied, the turnover rates in the 2010-11 and 2011-12 academic years were $16.24 \%$ and $18.27 \%$. Higher than average turnover rates were among women and minorities, especially those who are bi-racial, those who earn less than $\$ 40,000$ per year, nonfaculty, and those who had worked at the institution for fewer than five years. For the entire system consisting of 11 universities, the turnover rates for those years were $15.87 \%$ and $19.26 \%$, and the turnover exhibited the same pattern among the groups mentioned for the single university in that university system.

Retention of employees, then, frequently rises to the forefront in the minds of college and university administrators. Salary, health and retirement benefits are not the only facets of an employment package to be considered. According to a report by the Association for the Study of Higher Education (ASHE, 2012), recruitment and retention of college and university employees depend upon total rewards. In a time when people working at colleges and universities feel the effects of budget cuts, job loss and working days stretched to the limits (Levin, 2005; Meyerhoff, Johnson, \& Braun, 2011); where distinctions between the economy and society no longer exist because performance is based primarily on economic indicators (Lemke, 2001; Saunders, 2010); where workers in higher education struggle to improve their position (Berry \& Worthen, 2012); and where polarization in the workforce means the bottom tier barely scrapes by (Berry \& Worthen, 2012), working conditions, such as salary and overall environment are considered to be important indicators of employment satisfaction and engagement (Hermsem \& Rosser, 2008).

This study separately measures two primary dependent variables: (a) intended employee retention; and (b) intended employee productivity for several levels of dependent tuition waivers: $10 \%, 15 \%, 20 \%, 25 \%, 50 \%, 75 \%$ and $100 \%$. The study controls for experience, age, gender, faculty or staff status, annual salary, and number of dependents in the set of independent 
variables. Additionally, this study explores what level of tuition reduction maximizes employee productivity and retention. Finally, we examine the expected net cost and net benefit to the university at one proposed level of tuition reduction, based on marginally increased enrollment of faculty/staff dependents at the university.

The amount of the tuition waiver, number of dependents, and annual salary are all statistically significant predictors of intended increased productivity and intent to stay at the current institution. Additionally, faculty or staff classification is also statistically significant for the intent to stay. This study also examines the expected increase in dependent enrollment hours over the next one-year and five-year period and finds that the increase in enrollment hours curve is not linear: the slope of the curve becomes steeper once the tuition waiver reaches $25 \%$. At the institution studied, the estimated direct opportunity cost (reduction in revenue) as a percent of total budgeted revenue is less than $1 \%$ of total budgeted revenue in all cases, and generally less than $1 / 10$ of $1 \%$ for dependent tuition waivers of $50 \%$ or less. Our study has important policy implications for higher-education institutions. From a public policy standpoint, these results suggest that for higher-education institutions where faculty and staff retention and productivity are a priority, maximizing or offering dependent college tuition waiver may be a relatively lowcost benefit to increase intended retention and productivity.

Although pay, benefits, and organizational culture tend to be key indicators of job satisfaction, little attention is given to specific types of benefits. This study examines how a reduction in dependent college tuition for faculty and staff affects employees' intent to work harder and stay at their current institution. While intentions, not actions, are measured here, Armitage and Conner (2001) found that intent correlates strongly with action. 


\section{Literature Review}

Higher education in North America has been criticized for failing to transform itself to meet the changing needs of society (Power, 2013); much of the concern centers on higher education's adherence to outdated business models, lack of student access, and failure to adopt technological and pedagogical strategies to serve society better. Most of higher education is provided by public institutions, with the difficult task of balancing its responsibilities as an agent of public good with a societal shift focused on economic outcomes as its main priority (Saunders, 2010). This shift, as Berry and Worthen (2012) conveyed, is a reflection of neoliberal policy that has dominated the landscape since the 1970s, where nearly everything becomes a commodity. Neoliberalism can be summarized with three major concepts: (a) advancement of a free market; (b) minimal state interference and regulation of the economy; and (c) the importance of individuals as economic actors (Plehwe et al., 2006; Saunders, 2010; Turner, 2008). In many regards, the critics of public institutions charge them to become more competitive in a free market, with a focus on performance as measured in financial terms (Radice, 2013), for increased productivity of personnel, services and goods (Meyerhoff et al., 2011), and for individuals to pursue economic advantages (Fredman \& Doughney, 2012). If there is a need for higher education to change according to societal needs, it must also respond to changing needs of its employees as individuals pursuing their own economic advantages.

With a recently strengthening economy and an enduring neoliberal foundation, institutions of higher education are increasingly aware of and concerned about losing personnel to non-academic industries that can offer higher pay and better benefits (Bozeman \& Gaughan, 2011). Whether employees are faculty, staff, or administrators, they "tend to be satisfied if they feel their pay reflects their market value and if they have the respect of their co-workers” 
(Bozeman \& Gaughan, 2011, p. 178). In instances in which the paycheck does not reflect market value, other employment conditions could make continuing employment worthwhile.

These conditions often vary among different classifications of employees, such as administrators, staff, and faculty. Among different types of administrators, Howard-Baldwin et al. (2012) found that job satisfaction depends upon work climate, which includes job assignment, pay, promotion, supervision, recognition and interaction with colleagues. Hermsen and Rosser (2008) examined job satisfaction among staff members in colleges as it pertains to responsibility, recognition, advancement, training, connectedness to others, discrimination, relationships with external constituents, autonomy, and organizational culture. They found that career support, recognition, working conditions, external relations, and role fit are statistically significant but cautioned that where there is concern about increased costs, limited budgets, and budget impact on salaries and working conditions, institutions must find ways to foster engagement and satisfaction. Hermsen and Rosser (2008) indicated that career support, recognition, working conditions, external relations, and role fit are important for employee retention. Thus, a prototype/willingness model may help explain behavior or intended behavior (Gibbons et al., 1998). It suggested that within the theory of planned behavior, behavior is often reactive based on an immediate situation. Ultimately, behavior is contained within a person's controlled beliefs (Azjen, 2011). Among faculty, Bozeman and Gaughan (2011) found that more hours of undergraduate teaching tended to reduce job satisfaction, and research and grant writing have no effect; but the most important predictors of faculty job satisfaction are one's contributions to the field, followed by being paid what one is worth in a comparable market. Moors, Malley and Stewart (2014) found that those institutions seeking gender balance in the sciences, technology, engineering, math and medical science (STEMM) fields particularly benefit from being 
perceived as supportive of family commitments, because women in STEMM fields with low institutional support for family commitments had significantly less job satisfaction and sense of belonging than comparable men.

Nationally, higher education finds itself under tremendous strain (Altbach, 2011). Public higher education is criticized for being wasteful and inefficient as compared to for-profit businesses, and therefore undeserving of state support. Anderson et al. (2002) provided evidence that university employees consider their workplaces to have less family-friendly policies than corporate employees. The professoriate is often the target of the criticism. This is not a new problem. Finkelstein (2001) related a public indictment of faculty, that they have scurrilous motives, portray a poorly developed work ethic, act with complacency, and show a lack of accountability. Although public anxiety often sees higher education through the eyes of the media (Fischer, 2011), higher education is “one of the central institutions of postindustrial society,” and faculty are crucial to its success (Altbach, 2011, p. 228). Full-time faculty workloads at assistant, associate, and full professor levels exceed 50 hours a week (Jacobs \& Winslow, 2004). But, mostly to save money, colleges and universities use an increasing number of part-time faculty and “professional” faculty, who are paid much less because they are available in the local economy and are not expected to engage in university service or scholarly activity. In a study of 1401 colleges and universities across the U.S., Zhang and Liu (2010) found that across all higher education institutions, a 10\% increase in revenues decreases the use of parttime faculty by only $1.8 \%$, while the same $10 \%$ increase in institutional revenue increases the number of full-time and professional faculty $6.1 \%$ and $5 \%$, respectively. A $1 \%$ increase in faculty salaries leads to $.85 \%$ increase in hiring part-time faculty and reduces the employment 
level of full-time faculty by .76\%. Although the public may lack confidence in higher education, the work is complex, but is it adequately rewarded?

Private universities have long allowed the dependents of faculty members to attend the university where the faculty member is employed at reduced tuition, or more often, paying no tuition. Some institutions participate in an exchange, where a faculty member employed by a participating university can use a dependent tuition waiver at other colleges in the same exchange. One such exchange (http://www.tuitionexchange.org/) boasts over 625 participating public or private institutions across the U.S. and Canada. Dur and Unver (2012) asserted that tuition exchange programs play a prominent role in helping small institutions compete with bigger schools in hiring the best faculty. More specifically, Manchester (2012) found that desirable employees self-select firms with employer-sponsored tuition reimbursement programs more often than firms that do not; he also measured a secondary, direct effect on retention due to employee participation in this type of program. Several studies provide evidence that there is a positive relationship between tuition reimbursement and retention of employees (Flaherty, 2007; Pattie et al., 2006). However, there is no other study that examines what percent of tuition reimbursement affects retention. Colleges and universities are becoming more and more mindful of their competitive market and bottom line. As such, it would be prudent to scrutinize what levels of tuition reimbursements work best for each campus. Further, Friedenthal et al. (1973) found tuition remission provided a financial benefit to faculty and, although it is a familyfriendly benefit that favors faculty with children, it has a minimal discriminatory effect because its value to the individual faculty member is generally factored into the compensation package at the time of hire. Galinsky et al. (1996) found that employees who are parents considered familyfriendly policies significantly more important than did non-parents. 


\section{Research Questions}

Literature and experience have shown that benefits, and in particular, dependent tuition waivers, are valuable employee benefits for many private and public colleges and universities. Given that tuition has risen dramatically at public institutions over the past 20 years and more, would a similar benefit now be valuable to such a university? To shed light on this issue, this study examines value as having qualitative benefits to the university of increased employee retention and increased employee productivity, and having additional (marginal) costs to the university that quantitatively are relatively small compared to the total budgeted revenues. Specifically, the following research questions are the focus of this study:

$\mathrm{RQ}_{1}$ : Do any of eight various levels of dependent college tuition waivers (ranging from $0 \%-100 \%$ ) have a significant effect on the intent of faculty (staff) to work harder?

$\mathrm{RQ}_{2}$ : Do any of eight various levels of dependent college tuition waivers (ranging from $0 \%-100 \%$ ) have a significant effect on the intent of faculty (staff) to stay at their current institution?

$\mathrm{RQ}_{3}$ : How much enrollment (in student credit hours) can administration expect if the institution provides dependent tuition waivers?

$\mathrm{RQ}_{4}$ : What is the estimated direct opportunity cost of this benefit as a percent of total revenue?

Note that the indirect benefits to the University of offering such a program are not measured. These benefits may include a more family-friendly workplace and campus environment, faculty and staff without dependents feeling that the university cares for its 
employees and additional ancillary revenues that accrue from students attending this particular university over another.

\section{Data, Methodology and Analysis}

\section{1. Data}

The study utilizes a unique data set that is constructed by surveying full-time faculty and staff members at a public university. An email was sent to approximately 1060 full-time faculty and staff members in the university employee email address list, requesting that they complete an online survey. The survey responses were anonymous, and two additional follow-up emails were sent at six week intervals to all faculty/staff, requesting that they fill out the survey if they had not already done so. ${ }^{1}$ The faculty and staff answered detailed questions about their work experience, skills, work pressures, personal and family characteristics and their attitudes towards tuition reductions. ${ }^{2}$ Survey questions were designed so that most questions were Likert scaled over seven numbers titled as “strongly disagree” to "strongly agree.” Some items were reverse coded to prevent “foot-in-the-door syndrome,” (Freedman and Fraser, 1966); that is, to make respondents read each of the questions carefully, in order to minimize the likelihood that an individual will lessen her effort by choosing the same Likert response for multiple questions. Of the 1060 full-time faculty and staff members, a total of 486 employees responded which produced 462 usable responses.

\section{2. Methodology and Analysis}

\footnotetext{
${ }^{1}$ This online survey system allowed only one response sent from any university email account to ensure that no one person could easily complete the instrument twice.

${ }^{2}$ The complete survey instrument can be found in Appendix A.
} 
To study the relationship between the levels of dependent tuition waivers and intended employee retention and intended employee productivity, ordinary least squares is used to estimate the following empirical model for each intended outcome:

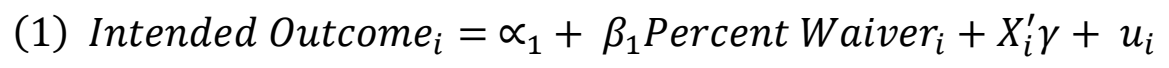

where Intended Outcome $e_{i}$ is one of two intended outcomes (intended employee retention and intended employee productivity) for employee $i$. Each of the intended outcomes is estimated separately. Intended employee retention (intent to stay at current institution) is measured using a 7-point Likert scale (with 3 being Strongly Agree and -3 being Strongly Disagree) answers to the following prompt "I would be more likely to stay at this institution" for various levels of potential dependent tuition waivers. Intended employee productivity (intent to work harder) is measured similarly using a 7-point Likert scale (3 assigned as Strongly Agree and -3 assigned as Strongly Disagree) answers to the following prompt "I would work harder at this job than I currently do" for various levels of potential dependent tuition waivers. To be able to conduct empirical modeling and estimation, the Likert scale rankings were converted to 0-6 scale with 6 being Strongly Agree and 0 being Strongly Disagree. Percent Waiver $r_{i}$ is the main independent variable that takes on the following values of potential tuition percent waivers 10 , $15,20,25,50,75$, and $100 \% . X_{i}^{\prime}$ is a vector of independent variables that contains years of experience at the current institution, age of the respondent, dummy for gender (takes on a value of one for male employees), dummy for faculty/staff status (takes on a value of one for faculty), number of dependents, and annual salary (Survey respondents were asked to choose one of the

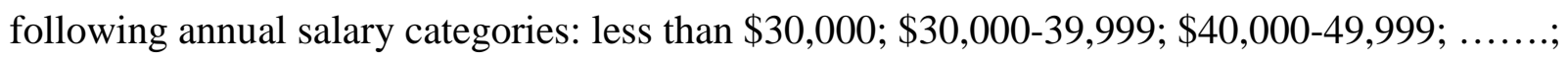
$\$ 160,000-169,999 ; \$ 170,000$ and more. Annual salary is measured in thousands, bottom-coded at $\$ 30,000$ and coded as midpoints to the intervals after the "less than $\$ 30,000$ " category). $u_{i}$ is the 
error term for two outcome equations where $\mathrm{E}\left(u_{i}\right)=0$ and $\operatorname{Var}\left(u_{i}\right)=\sigma^{2}$. The main coefficient of interest is $\beta_{1}$ and $\gamma$ is a vector of parameters for other independent variables. First, Equation (1) is estimated for each intent measures by using an OLS model. However, because employee responses to the questions that measure productivity and retention intent are inherently ordered, it is appropriate to use the ordered probit model.

To study the relationship between dependent tuition waiver and employee labor supply behavior, the following ordered probit model was estimated: ${ }^{3}$

$$
\text { (2) } I O_{i j}^{*}=\theta_{j} \text { Percent }_{\text {Waiver }}+X_{i j}^{\prime} \varphi_{j}+\varepsilon_{i j}
$$

where $I O_{i j}^{*}$ is the importance $j$ (as measured 7 point scale ranking with 0 being Strongly Disagree and 6 being Strongly Agree) employee $i$ assigns to the Intended Outcome (intent to stay at the current institution or intent to work harder). Percent $W$ aiver ${ }_{i j}$ and $X_{i j}$ are defined previously. $\theta_{j}$ and $\varphi_{j}$ are regression parameters and $\varepsilon_{i j}$ is a stochastic error term.

Even though the latent variable $I O_{i j}^{*}$ is not observed, the ranking of responses of university employees to each of the questions is related to employee intent. Employee responses, $I O$, are defined as follows:

$$
\text { (3) } \begin{aligned}
I O=0, \quad \text { if } I O_{j}^{*} \leq \mu_{0 j} \\
=1, \quad \text { if } \mu_{0 j}<I O_{j}^{*} \leq \mu_{1 j} \\
=2, \quad \text { if } \mu_{1 j}<I O_{j}^{*} \leq \mu_{2 j} \\
=3, \quad \text { if } \mu_{2 j}<I O_{j}^{*} \leq \mu_{3 j} \\
=4, \quad \text { if } \mu_{3 j}<I O_{j}^{*} \leq \mu_{4 j} \\
=5, \quad \text { if } \mu_{4 j}<I O_{j}^{*} \leq \mu_{5 j} \\
=6, \quad \text { if } \mu_{5 j} \leq I O_{j}^{*}
\end{aligned}
$$

\footnotetext{
${ }^{3}$ Please see Greene (2003) for more details on the general form of the ordered probit model.
} 
where each of the $\mu_{j}$ 's correspond to unknown threshold parameters for each 7-point ranking $j$. While the employees could respond with their own ranking of intent measures $I O^{*}$, with only 7 choices, individuals will pick the ranking that is closest to their own ranking. As per the assumptions of the ordered probit model, the stochastic error term, $\varepsilon_{i j}$, is normally distributed with zero mean and a variance of 1 . Given the standard assumption of the ordered probit model, and let $\theta_{j}{\text { Percent } \text { Waiver }_{i j}}+X_{i j}^{\prime} \varphi_{j}=\boldsymbol{Z}^{\prime} \boldsymbol{\beta}$ in equation (2) $I O_{i j}^{*}=\theta_{j}{\text { Percent } \text { Waiver }_{i j}+}^{+}$ $X_{i j}^{\prime} \varphi_{j}+\varepsilon_{i j}$, the following probabilities are derived:

$$
\text { (4) } \begin{aligned}
& \operatorname{Prob}(I O=0)=\Phi\left(-Z^{\prime} \beta\right) \\
& \operatorname{Prob}(I O=1)=\Phi\left(\mu_{1 j}-Z^{\prime} \beta\right)-\Phi\left(-Z^{\prime} \beta\right) \\
& \operatorname{Prob}(I O=2)=\Phi\left(\mu_{2 j}-Z^{\prime} \beta\right)-\Phi\left(\mu_{1 j}-Z^{\prime} \beta\right) \\
& \operatorname{Prob}(I O=3)=\Phi\left(\mu_{3 j}-Z^{\prime} \beta\right)-\Phi\left(\mu_{2 j}-Z^{\prime} \beta\right) \\
& \operatorname{Prob}(I O=4)=\Phi\left(\mu_{4 j}-Z^{\prime} \beta\right)-\Phi\left(\mu_{3 j}-Z^{\prime} \beta\right) \\
& \operatorname{Prob}(I O=5)=\Phi\left(\mu_{5 j}-Z^{\prime} \beta\right)-\Phi\left(\mu_{4 j}-Z^{\prime} \beta\right) \\
& \operatorname{Prob}(I O=6)=1-\Phi\left(\mu_{5 j}-Z^{\prime} \beta\right)
\end{aligned}
$$

where $\Phi($.$) is the cumulative density function for a normal random variable. In order to ensure$ positive probabilities, $0<\mu_{1 j}<\mu_{2 j}<\mu_{3 j}<\mu_{4 j}<\mu_{5 j}$ is required.

\section{Results}

Of the 424 usable responses to the faculty/staff status question, 56\% identified themselves as staff, $42 \%$ as faculty, $2 \%$ as other and 62 individuals did not respond to this question. The largest portion of the sample (31\%) are aged $45-54$, followed by $27 \%$ aged $35-44$, 19\% aged 55-64, 15\% aged 24-34 and only 5.8\% aged 65-74. The average respondent had 14 years of experience at the institution, 1.8 dependents and annual income of $\$ 56,945$. Sixty-five 
percent of respondents were female and 35\% were male. Additional descriptive statistics are provided in Table 1. 


\section{Table 1: Summary Statistics}

\begin{tabular}{|c|c|c|c|c|c|}
\hline Variable & Mean & $\begin{array}{c}\text { Standard } \\
\text { Deviation }\end{array}$ & Minimum & Maximum & Observations \\
\hline Male & 0.353 & 0.478 & 0 & 1 & 416 \\
\hline Female & 0.646 & 0.478 & 0 & 1 & 416 \\
\hline \multicolumn{6}{|l|}{ Status } \\
\hline Faculty & 0.419 & 0.494 & 0 & 1 & 424 \\
\hline Staff & 0.559 & 0.497 & 0 & 1 & 424 \\
\hline Other & 0.021 & 0.144 & 0 & 1 & 424 \\
\hline \multicolumn{6}{|l|}{ Age Interval } \\
\hline 18 to 24 & 0.016 & 0.127 & 0 & 1 & 424 \\
\hline 25 to 34 & 0.151 & 0.358 & 0 & 1 & 424 \\
\hline 35 to 44 & 0.271 & 0.445 & 0 & 1 & 424 \\
\hline 45 to 54 & 0.313 & 0.464 & 0 & 1 & 424 \\
\hline 55 to 64 & 0.186 & 0.389 & 0 & 1 & 424 \\
\hline 65 to 74 & 0.058 & 0.232 & 0 & 1 & 424 \\
\hline 75 or older & 0.002 & 0.048 & 0 & 1 & 424 \\
\hline Experience & 13.82 & 9.509 & 1 & 55 & 404 \\
\hline $\begin{array}{l}\text { Number of } \\
\text { Dependents } \\
\text { Annual }\end{array}$ & 1.824 & 1.522 & 0 & 10 & 462 \\
\hline Income & $\$ 56,945$ & $\$ 25,232$ & $\$ 30,000$ & $\$ 170,000$ & 424 \\
\hline
\end{tabular}

Figure 1 presents the response distributions for intended employee retention (intent to stay at current institution) and intended employee productivity (intent to work harder) at 10, 15, 20, 25, 50, 75 and 100\% tuition waivers for dependents (both outcomes are measured using a 7point Likert scale with 3 being Strongly Agree and -3 being Strongly Disagree). Figure 1 provides evidence that respondents' intention to work harder and intention to stay at the institution are increasing functions of the tuition waivers, with intention to stay responding stronger to higher percentages of tuition waivers. Although none of the covariates are accounted for in a regression modeling framework, Figure 1 shows that intent to stay and intent work harder may be related to the tuition waivers for dependents. 
Figure 1: Distributions of Intended Employee Productivity and Intended Employee

\section{Retention at Various Levels of Tuition Waivers for Dependents}
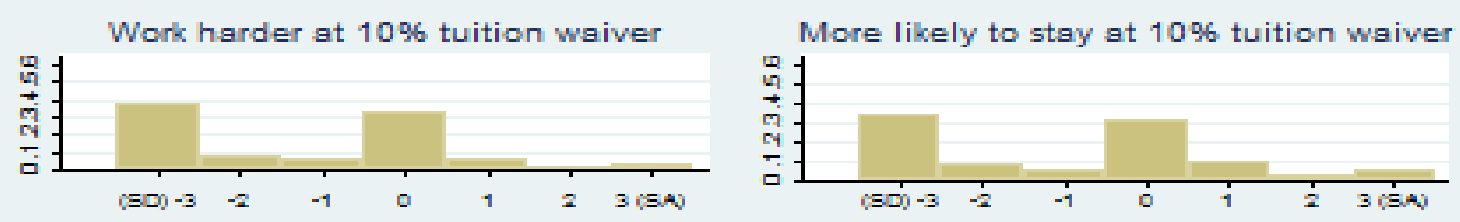

Work harder at $15 \%$ tuition waiver
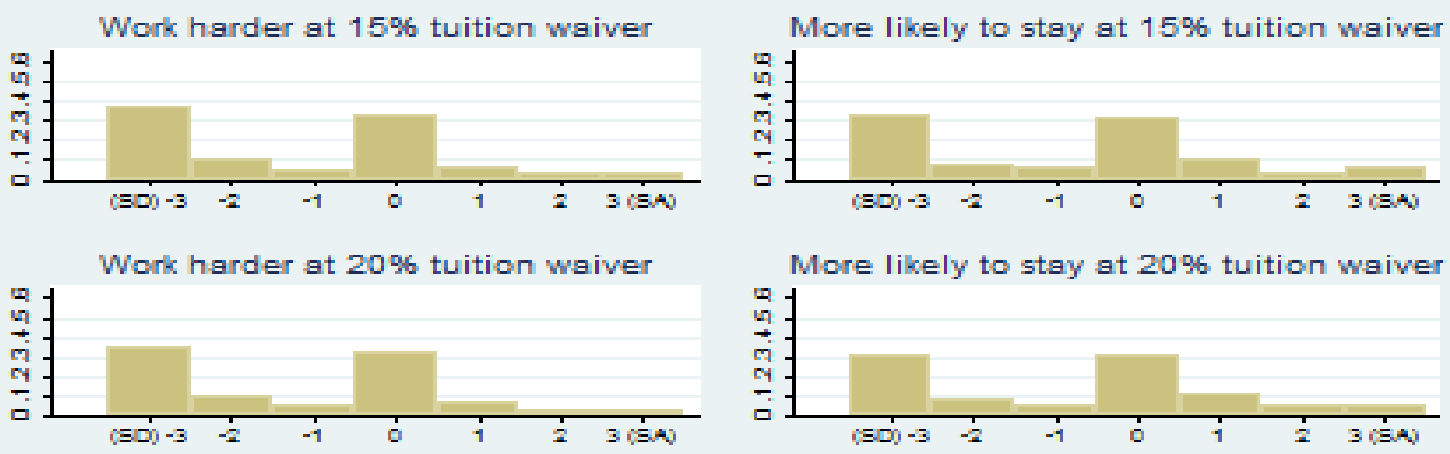

More likely to stay at 2096 tuition waiver \begin{tabular}{l} 
a \\
an \\
mi \\
cy \\
\hline
\end{tabular}

Work harder at $25 \%$ tuition waiver
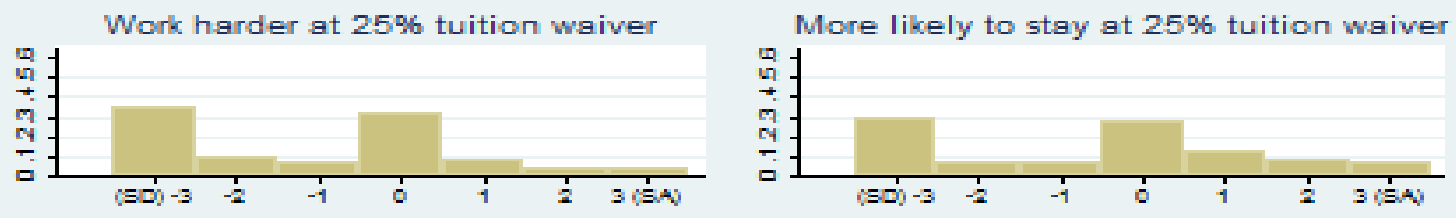

Work harder at $50 \%$ tuition waiver

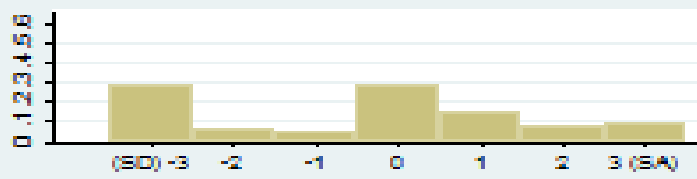

More likely to stay at $50 \% 6$ tuition waiver

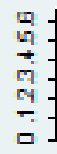

Work harder at $75 \%$ tuition waiver
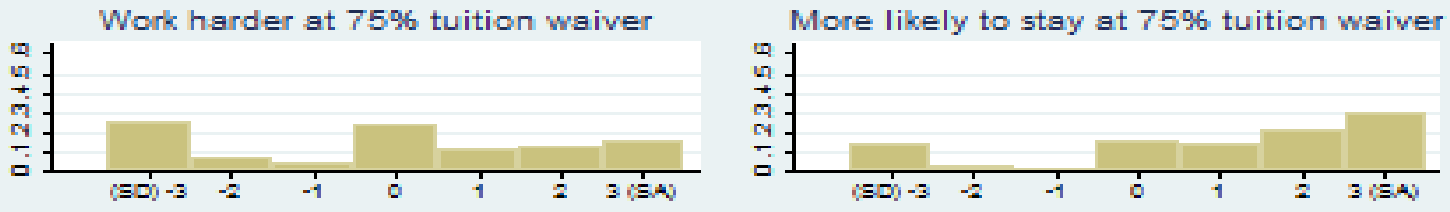

Work harder at $100 \%$ tuition waiver More likely to stay at $100 \%$ tuition waiver
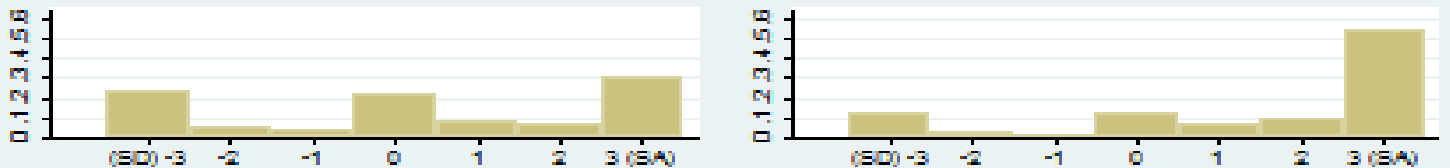
Table 2 shows the OLS regression results for intent to work harder (column 1) and intent to stay at current institution (column 2). The first column of Table 2 presents the coefficient estimates for intent to increase productivity and the regression results have an R-squared of 0.168. As expected, the percentage tuition waiver has a highly statistically significant (t-value $=$ 12.44) positive coefficient, suggesting that the greater the dependent tuition waiver, the greater the intended increase in productivity.

Two other independent variables are statistically significant at the one percent level: the respondent's annual salary (negative coefficient) and the number of dependents (positive coefficient). The lower the salary, the greater the increase in productivity; and the higher the number of dependents, the greater the increase in productivity. Faculty dummy, gender and age do not have statistically significant coefficients.

Column 2 of Table 2 shows that, for retention (the intent to stay at the current institution), the regression model has an R-squared of 0.278 . Four independent variables were statistically significant: the percent of the waiver, faculty dummy, the respondent's annual salary and the number of dependents. As with intent to increase productivity, the percent of the waiver was statistically significant and positive, indicating that the larger the tuition waiver, the greater the intent to stay, potentially reducing employee turnover costs.

The results indicate that the lower the salary, the lower the intent to stay; and the higher the number of dependents, the greater the intent to stay. In the case of intended retention, faculty members were less likely to intend to stay compared to staff members. 
Table 2: OLS Models for Intent to Work Harder and Intent to Stay at Current Institution

\begin{tabular}{|c|c|c|}
\hline Variable & $\begin{array}{c}\text { Intent to Work } \\
\text { Harder }\end{array}$ & $\begin{array}{l}\text { Intent to Stay at } \\
\text { Current Institution }\end{array}$ \\
\hline Tuition Waiver \% & $\begin{array}{c}0.0172 * * * \\
(12.44)\end{array}$ & $\begin{array}{c}0.0279 * * * \\
(18.78)\end{array}$ \\
\hline Male & $\begin{array}{c}-0.00794 \\
(0.04)\end{array}$ & $\begin{array}{c}0.192 \\
(1.11)\end{array}$ \\
\hline Faculty & $\begin{array}{c}-0.298 \\
(1.50)\end{array}$ & $\begin{array}{c}-0.383^{* *} \\
(2.08)\end{array}$ \\
\hline Age & & \\
\hline 18 to 24 & $\cdot$ & $\begin{array}{l}-20.42 \\
(1.00)\end{array}$ \\
\hline 25 to 34 & $\begin{array}{l}1.120 \\
(1.02)\end{array}$ & $\begin{array}{l}-20.89 \\
(1.03)\end{array}$ \\
\hline 35 to 44 & $\begin{array}{l}0.887 \\
(0.81)\end{array}$ & $\begin{array}{l}-20.93 \\
(1.03)\end{array}$ \\
\hline 45 to 54 & $\begin{array}{l}0.999 \\
(0.90)\end{array}$ & $\begin{array}{l}-20.98 \\
(1.03)\end{array}$ \\
\hline 55 to 64 & $\begin{array}{l}0.727 \\
(0.65)\end{array}$ & $\begin{array}{l}-21.33 \\
(1.05)\end{array}$ \\
\hline 65 to 74 & $\begin{array}{l}1.505 \\
(1.25)\end{array}$ & $\begin{array}{l}-20.46 \\
(1.00)\end{array}$ \\
\hline 75 and older & . & . \\
\hline Experience & $\begin{array}{c}0.00102 \\
(0.03)\end{array}$ & $\begin{array}{c}0.00745 \\
(0.27)\end{array}$ \\
\hline Experience squared & $\begin{array}{c}0.00004 \\
(0.05)\end{array}$ & $\begin{array}{c}-0.0002 \\
(0.37)\end{array}$ \\
\hline Number of dependents & $\begin{array}{c}0.213^{* * *} \\
(3.52)\end{array}$ & $\begin{array}{c}0.315^{* * *} \\
(5.63)\end{array}$ \\
\hline Annual salary/1000 & $\begin{array}{c}-0.018 * * * \\
(4.28)\end{array}$ & $\begin{array}{c}-0.016 * * * \\
(3.85)\end{array}$ \\
\hline Constant & $\begin{array}{l}1.299 \\
(1.21) \\
\end{array}$ & $\begin{array}{l}23.03 \\
(1.13) \\
\end{array}$ \\
\hline$N$ & 2322 & 2412 \\
\hline Adj. $R^{2}$ & 0.168 & 0.278 \\
\hline
\end{tabular}

Notes: Regression of intent to work harder and intent to stay at current Institution on male dummy, faculty dummy, age, experience, experience squared, annual salary, and number of dependents. Intent to work harder and stay at current institution are measured using a 7-point Likert scale with 6 being Strongly Agree and 0 being Strongly Disagree. $t$-statistics are reported in parentheses and are in absolute values together with the coefficients which are estimated using OLS. Robust standard errors are clustered at the respondent level $* * *, * *$ and $*$ indicate respectively $1 \%, 5 \%$ and $10 \%$ significance levels $\left(* * * p<0.01,{ }^{* *} p<0.05, * p<0.10\right)$. 
Having established a positive relationship between dependent tuition waivers and employee productivity and retention using OLS, the results were verified using an ordered probit modeling framework that better fits to the dependent variables, which are ordinal in nature. The coefficient estimates for the ordered probit model and the six threshold parameters $\left(\mu_{0}\right.$ through $\left.\mu_{5}\right)$ are presented in Table 3.

Consistent with the OLS findings, Table 3 shows that dependent tuition waiver is associated with intent to increase productivity and intent to stay at current institution (tuition waiver $\%$ has positive and statistically significant coefficients at 1 percent level in both models). Faculty status has negative and statistically significant coefficient in the Intent to Stay equation, but not in Intent to Work Harder equation. Number of dependents is associated with higher intended productivity and retention and respondent salary has negative, statistically significant coefficient for both intents.

In this study, the ordered probit model is more appropriate than employing an OLS framework, because it accounts for the ordinal and categorical nature of the dependent variable. Tables 4 and 5 report marginal effects after estimating ordered probit models for each explanatory variable on each Likert-scale ranking in intent to work harder and intent to stay at current intuition equations respectively.

Table 4 shows that an increase in tuition waiver from no tuition waivers to completely free tuition for dependents decreases the probability of choosing Strongly Disagree in Intent to Work Harder equation by 30 percentage points, while it increases the probability of choosing Strongly Agree in Intent to Work Harder equation by 20 percentage points. 
Table 3:

\section{Ordered Probit Models for Intent to Work Harder and Intent to Stay at Current Institution: Coefficient Estimates}

\begin{tabular}{lcc}
\hline \multirow{2}{*}{ Variable } & Intent to & Intent to Stay at \\
& Work Harder & Current Institution \\
\hline Tuition Waiver \% & $0.0102^{* * *}$ & $0.017^{* * *}$ \\
Faculty & $(12.46)$ & $(17.02)$ \\
Number of dependents & -0.173 & $-0.211^{* *}$ \\
& $(1.45)$ & $(1.98)$ \\
Annual salary/1000 & $0.125^{* * *}$ & $0.186^{* * *}$ \\
& $(3.54)$ & $(5.62)$ \\
$\mu_{0}$ & $-0.0107^{* * *}$ & $-0.00927^{* * *}$ \\
& $(3.96)$ & $(3.59)$ \\
$\mu_{1}$ & $-0.864^{* *}$ & $-0.587^{*}$ \\
& $(2.34)$ & $(1.95)$ \\
$\mu_{2}$ & $-0.627^{*}$ & -0.377 \\
& $(1.70)$ & $(1.26)$ \\
$\mu_{3}$ & -0.478 & -0.228 \\
& $(1.30)$ & $(0.76)$ \\
$\mu_{4}$ & 0.405 & $0.534^{*}$ \\
& $(1.11)$ & $(1.79)$ \\
$\mu_{5}$ & $0.776^{* *}$ & $0.957^{* * *}$ \\
& $(2.13)$ & $(3.21)$ \\
\hline$N$ & $1.111^{* * *}$ & $1.367^{* * *}$ \\
Pog likelihood & $(3.02)$ & $(4.52)$ \\
\hline & 2322 & 2412 \\
& -3741.1 & -3921.3 \\
& 0.055 & 0.094 \\
& & \\
& &
\end{tabular}

Notes: Ordered probit model for intent to work harder and intent to stay at current Institution controlling for tuition waiver percentages, male dummy, faculty dummy, age, experience, experience squared, annual salary, and number of dependents. The coefficient estimates of variables that are not statistically significant at conventional levels (male dummy, age, experience and experience squared) are not reported to conserve space. The full set of results is available upon request from authors. Intent to work harder and stay at current institution are measured using a 7-point Likert scale with 3 being Strongly Agree and -3 being Strongly Disagree. Z-statistics are reported in parentheses and are in absolute values together with the coefficients which are estimated using ordered probit. Robust standard errors are clustered at the respondent level $* * *, * *$ and $*$ indicate respectively $1 \%, 5 \%$ and $10 \%$ significance levels $\left(* * * p<0.01,{ }^{* *} p<0.05,{ }^{*} p<0.10\right)$. 
The marginal effects of tuition waiver percentages for all seven outcomes in the Likertscale are statistically significant and the negative coefficient of tuition waivers becomes positive starting with the "Undecided (0)" outcome meaning that increased tuition waiver is associated with lower likelihood of choosing Strongly Disagree, Disagree, Disagree Somewhat and it is associated with higher likelihood of choosing Undecided, Agree Somewhat, Agree, and Strongly Agree for the intent to work harder outcome.

The increase in the number of dependents by one is associated with $4,0.3$ and 0.1 percentage point decreases in the probability of reporting Strongly Disagree, Disagree and Disagree Somewhat. On the other hand, respondents with one additional dependent are 0.2 percentage points more likely to choose Strongly Agree for the intent to work harder question. Every $\$ 10,000$ increase in respondents' salary is associated with a 3 percentage points higher likelihood of selecting Strongly Disagree for the intended productivity and a 1.7 percentage points lower likelihood of selecting Strongly Agree for the productivity.

Table 5 provides evidence that an increase in tuition waivers from $0 \%$ to $100 \%$ decreases the probability of choosing Strongly Disagree in intent to stay at the current institution by 40 percentage points, while it increases the probability of choosing Strongly Agree in intent to stay at the current institution by 40 percentage points. The marginal effects of tuition waivers for all but one outcome in the Likert-scale are statistically significant and the negative coefficient of tuition waivers becomes positive starting with the "Agree Somewhat (1)" outcome. 


\section{Table 4: Ordered Probit Marginal Effects of Intent to Work Harder}

\begin{tabular}{|c|c|c|c|c|c|c|c|}
\hline \multirow[b]{2}{*}{ Variable } & \multicolumn{4}{|c|}{ Marginal Effects of Intent to Work Harder } & \multirow[b]{2}{*}{$\begin{array}{c}\text { Agree } \\
\text { Somewhat } \\
\text { (1) }\end{array}$} & \multirow[b]{2}{*}{$\begin{array}{l}\text { Agree } \\
\text { (2) }\end{array}$} & \multirow[b]{2}{*}{$\begin{array}{l}\text { Strongly } \\
\text { Agree } \\
\text { (3) }\end{array}$} \\
\hline & $\begin{array}{c}\text { Strongly } \\
\text { Disagree } \\
(-3)\end{array}$ & Disagree & $\begin{array}{c}\text { Disagree } \\
\text { Somewhat } \\
(-1)\end{array}$ & $\begin{array}{c}\text { Undecided } \\
\text { (0) }\end{array}$ & & & \\
\hline $\begin{array}{l}\text { Tuition Waiver } \\
\%\end{array}$ & $\begin{array}{c}-0.003^{* * *} \\
(12.56)\end{array}$ & $\begin{array}{c}-0.0003^{* * *} \\
(4.33)\end{array}$ & $\begin{array}{c}-0.0001^{* * * *} \\
(2.89)\end{array}$ & $\begin{array}{l}0.0007 * * * \\
(5.17)\end{array}$ & $\begin{array}{c}0.0007 * * * \\
(7.03)\end{array}$ & $\begin{array}{l}0.0006^{* * *} \\
(6.13)\end{array}$ & $\begin{array}{c}0.002 * * * \\
(8.99)\end{array}$ \\
\hline Faculty & $\begin{array}{l}0.055 \\
(1.46)\end{array}$ & $\begin{array}{l}0.005 \\
(1.41)\end{array}$ & $\begin{array}{l}0.002 \\
(1.35)\end{array}$ & $\begin{array}{l}-0.011 \\
(1.41)\end{array}$ & $\begin{array}{l}-0.012 \\
(1.44)\end{array}$ & $\begin{array}{l}-0.011 \\
(1.45)\end{array}$ & $\begin{array}{l}-0.027 \\
(1.44)\end{array}$ \\
\hline $\begin{array}{l}\text { Number of } \\
\text { dependents }\end{array}$ & $\begin{array}{c}-0.040 * * * \\
(3.62)\end{array}$ & $\begin{array}{c}-0.003^{* * *} \\
(2.84)\end{array}$ & $\begin{array}{c}-0.001^{* *} \\
(2.30)\end{array}$ & $\begin{array}{c}0.008^{* * *} \\
(3.15)\end{array}$ & $\begin{array}{c}0.009 * * * \\
(3.46)\end{array}$ & $\begin{array}{c}0.008^{* * *} \\
(3.42)\end{array}$ & $\begin{array}{c}0.020 * * * \\
(3.29)\end{array}$ \\
\hline $\begin{array}{l}\text { Annual } \\
\text { salary/1000 }\end{array}$ & $\begin{array}{c}0.003 * * * \\
(4.09)\end{array}$ & $\begin{array}{c}-0.0003^{* * *} \\
(3.01)\end{array}$ & $\begin{array}{c}-0.0001^{* *} \\
(2.39)\end{array}$ & $\begin{array}{c}-0.0007 * * * \\
(3.42)\end{array}$ & $\begin{array}{c}-0.0007 * * * \\
(3.89)\end{array}$ & $\begin{array}{c}-0.0007 * * * \\
(3.61)\end{array}$ & $\begin{array}{c}-0.0017 * * * \\
(3.68)\end{array}$ \\
\hline \multicolumn{8}{|c|}{$\begin{array}{l}\text { Notes: Marginal effects at sample averages calculated after ordered probit model for intent to work harder } \\
\text { controlling for tuition waiver percentages, male dummy, faculty dummy, age, experience, experience squared, } \\
\text { annual salary, and number of dependents. The coefficient estimates of variables that are not statistically significant } \\
\text { at conventional levels (male dummy, age, experience and experience squared) are not reported to conserve space. } \\
\text { The full set of results is available upon request from authors. Intent to work harder is measured using a } 7 \text {-point } \\
\text { Likert scale with } 3 \text { being Strongly Agree and }-3 \text { being Strongly Disagree. } z \text {-statistics are reported in parentheses } \\
\text { and are in absolute values together with the coefficients which are estimated using ordered probit. Robust standard } \\
\text { errors are clustered at the respondent level } * * * \text {, ** and * indicate respectively } 1 \% \text {, } 5 \% \text { and } 10 \% \text { significance levels } \\
(* * * p<0.01, * * p<0.05, * p<0.10) \text {. }\end{array}$} \\
\hline
\end{tabular}

Increase in the number of dependents by one is associated with 5, 0.5 and 0.3 percentage

point decreases in the probability of reporting Strongly Disagree, Disagree and Disagree

Somewhat, respectively. On the other hand, respondents with one additional dependent are 4

percentage points more likely to choose Strongly Agree for the intent to stay question. Every

$\$ 10,000$ increase in respondents’ salary is associated with a 2 percentage points higher likelihood

of selecting Strongly Disagree for the intended retention and it is associated with a 2 percentage

points lower likelihood of selecting Strongly Agree for the retention question. 
Table 5: Ordered Probit Marginal Effects for Intent to Stay at Current Institution

\begin{tabular}{|c|c|c|c|c|c|c|c|}
\hline \multirow[b]{2}{*}{ Variable } & \multicolumn{7}{|c|}{ Marginal Effects in intent to stay at current institution } \\
\hline & $\begin{array}{c}\text { Strongly } \\
\text { Disagree } \\
(-3)\end{array}$ & $\begin{array}{c}\text { Disagree } \\
(-2)\end{array}$ & $\begin{array}{c}\text { Disagree } \\
\text { Somewhat } \\
(-1)\end{array}$ & $\begin{array}{l}\text { Undecided } \\
\text { (0) }\end{array}$ & $\begin{array}{c}\text { Agree } \\
\text { Somewhat } \\
\text { (1) }\end{array}$ & $\begin{array}{l}\text { Agree } \\
\text { (2) }\end{array}$ & $\begin{array}{c}\text { Strongly } \\
\text { Agree } \\
\text { (3) }\end{array}$ \\
\hline $\begin{array}{l}\text { Tuition Waiver } \\
\%\end{array}$ & $\begin{array}{c}-0.004^{* * *} \\
(15.75)\end{array}$ & $\begin{array}{c}-0.0004^{* * *} \\
(5.17)\end{array}$ & $\begin{array}{c}-0.0003^{* * *} \\
\quad(4.70)\end{array}$ & $\begin{array}{l}-0.0002 \\
(1.37)\end{array}$ & $\begin{array}{c}0.0007^{* * *} \\
(7.32)\end{array}$ & $\begin{array}{c}0.001^{* * *} \\
(8.26)\end{array}$ & $\begin{array}{c}0.004 * * * \\
(16.76)\end{array}$ \\
\hline Faculty & $\begin{array}{c}0.055^{* *} \\
(1.98)\end{array}$ & $\begin{array}{c}0.006^{*} \\
(1.91)\end{array}$ & $\begin{array}{l}0.003^{*} \\
(1.89)\end{array}$ & $\begin{array}{l}0.002 \\
(1.11)\end{array}$ & $\begin{array}{c}-0.009 * * \\
(1.96)\end{array}$ & $\begin{array}{c}-0.013^{* *} \\
(1.98)\end{array}$ & $\begin{array}{c}-0.045^{* *} \\
(1.97)\end{array}$ \\
\hline $\begin{array}{l}\text { Number of } \\
\text { dependents }\end{array}$ & $\begin{array}{c}-0.049 * * * \\
(5.72)\end{array}$ & $\begin{array}{c}-0.005^{* * *} \\
(3.93)\end{array}$ & $\begin{array}{c}-0.003^{* * *} \\
(3.82)\end{array}$ & $\begin{array}{l}-0.002 \\
(1.32)\end{array}$ & $\begin{array}{c}0.008^{* * *} \\
(5.11)\end{array}$ & $\begin{array}{c}0.011^{* * *} \\
(5.48)\end{array}$ & $\begin{array}{c}0.040^{* * *} \\
(5.39)\end{array}$ \\
\hline Annual salary/1000 & $\begin{array}{c}0.002^{* * *} \\
(3.66)\end{array}$ & $\begin{array}{c}0.0003^{* * *} \\
(2.98)\end{array}$ & $\begin{array}{c}0.0001^{* * * *} \\
(2.94)\end{array}$ & $\begin{array}{l}0.0001 \\
(1.29)\end{array}$ & $\begin{array}{c}-0.0004^{* * *} \\
(3.51)\end{array}$ & $\begin{array}{c}-0.0006^{* * * *} \\
(3.47)\end{array}$ & $\begin{array}{c}-0.002 * * * \\
(3.60)\end{array}$ \\
\hline
\end{tabular}

Notes: Marginal effects at sample averages calculated after ordered probit model for stay at current institution controlling for tuition waiver percentages, male dummy, faculty dummy, age, experience, experience squared, annual salary, and number of dependents. The coefficient estimates of variables that are not statistically significant at conventional levels (male dummy, age, experience and experience squared) are not reported to conserve space. The full set of results is available upon request from authors. Intent to stay at current institution is measured using a 7-point Likert scale with 3 being Strongly Agree and -3 being Strongly Disagree. $z$-statistics are reported in parentheses and are in absolute values together with the coefficients which are estimated using ordered probit. Robust standard errors are clustered at the respondent level ***, ** and * indicate respectively $1 \%, 5 \%$ and $10 \%$ significance levels $(* * * p<0.01, * * p<0.05, * p<0.10$ ).

\section{1. How many credit hours do employee dependents plan to use at each level of dependent tuition waiver?}

These results suggest that currently, employees’ dependents enroll for an average of 3.84 credit hours per year. This is projected to rise as dependent tuition waivers increase. For both intent to increase productivity and intent to stay, the relationship between salary and intent does not appear to be entirely linear. Somewhere between $\$ 80,000$ and $\$ 89,999$ of annual salary range, the tuition waiver seems to lose some of its effectiveness. Descriptively, this is apparent from Table 6. Panel A of Table 6 shows the mean number of expected hours dependents will enroll over the next year and over the next 5 years for all faculty and staff. Panel B of Table 6 
shows the same information for those making under $\$ 80,000$, and Panel $\mathrm{C}$ of Table 6 shows that same information for those making over $\$ 80,000$. At all but the upper extreme of dependent tuition waivers, lower income respondents expect to use the dependent tuition waiver more than upper income respondents.

Table 6A: Number of Expected Hours of Dependent Enrollment, All Income Levels

\begin{tabular}{|c|c|c|c|c|c|c|c|c|}
\hline $\begin{array}{l}\text { Academic } \\
\text { Hour } \\
\text { Enrollment }\end{array}$ & $0 \%$ & $10 \%$ & $15 \%$ & $20 \%$ & $25 \%$ & $50 \%$ & $75 \%$ & $100 \%$ \\
\hline \multicolumn{9}{|l|}{ Over 1 Year } \\
\hline $\begin{array}{l}\text { Mean } \\
\text { Standard }\end{array}$ & 3.840 & 4.094 & 4.179 & 4.415 & 4.538 & 6.829 & 8.361 & 11.310 \\
\hline Deviation & 10.345 & 10.896 & 10.952 & 11.115 & 11.211 & 12.673 & 13.159 & 16.244 \\
\hline Minimum & 0 & 0 & 0 & 0 & 0 & 0 & 0 & 0 \\
\hline Maximum & 60 & 60 & 60 & 60 & 60 & 84 & 84 & 180 \\
\hline Count & 319 & 316 & 313 & 313 & 314 & 315 & 316 & 329 \\
\hline $\begin{array}{l}\text { Academic } \\
\text { Hour } \\
\text { Enrollment }\end{array}$ & $0 \%$ & $10 \%$ & $15 \%$ & $20 \%$ & $25 \%$ & $50 \%$ & $75 \%$ & $100 \%$ \\
\hline Over 5 Years & & & & & & & & \\
\hline $\begin{array}{l}\text { Mean } \\
\text { Standard }\end{array}$ & 13.069 & 13.535 & 13.735 & 14.633 & 15.206 & 26.481 & 34.266 & 46.346 \\
\hline Deviation & 37.892 & 38.133 & 38.234 & 38.862 & 38.911 & 44.809 & 51.142 & 64.371 \\
\hline Minimum & 0 & 0 & 0 & 0 & 0 & 0 & 0 & 0 \\
\hline Maximum & 300 & 300 & 300 & 300 & 300 & 300 & 320 & 540 \\
\hline Count & 318 & 314 & 313 & 311 & 315 & 314 & 319 & 329 \\
\hline
\end{tabular}

Table 6B: Number of Expected Hours of Dependent Enrollment, \$40,000 - \$80,000

*Note: There are 24 blank responses.

\begin{tabular}{lrrrrrrrr}
\hline $\begin{array}{l}\text { Academic } \\
\text { Hour } \\
\text { Enrollment }\end{array}$ & \multicolumn{1}{c}{$0 \%$} & \multicolumn{1}{c}{$10 \%$} & $15 \%$ & $20 \%$ & $25 \%$ & $50 \%$ & $75 \%$ & $100 \%$ \\
\hline $\begin{array}{l}\text { Over 1 Year } \\
\text { Mean }\end{array}$ & 4.519 & 4.912 & 5.006 & 5.061 & 5.328 & 7.901 & 9.315 & 11.929 \\
$\begin{array}{l}\text { Standard } \\
\text { Deviation }\end{array}$ & 11.880 & 12.632 & 12.691 & 12.788 & 13.004 & 14.251 & 14.668 & 18.840 \\
Minimum & 0 & 0 & 0 & 0 & 0 & 0 & 0 & 0 \\
Maximum & 60 & 60 & 60 & 60 & 60 & 84 & 84 & 180
\end{tabular}




\begin{tabular}{lrrrrrrrr} 
Count & 181 & 181 & 179 & 180 & 180 & 181 & 181 & 184 \\
\hline $\begin{array}{l}\text { Academic } \\
\text { Hour }\end{array}$ & & & & & & & & \\
Enrollment & $0 \%$ & $10 \%$ & $15 \%$ & $20 \%$ & $25 \%$ & $50 \%$ & $75 \%$ & $100 \%$ \\
\hline Over 5 Years & & & & & & & & \\
Mean & 15.093 & 16.808 & 16.950 & 17.833 & 18.481 & 30.912 & 39.130 & 51.663 \\
Standard & & & & & & & & \\
Deviation & 43.925 & 45.487 & 45.672 & 46.413 & 46.361 & 50.891 & 56.333 & 73.554 \\
Minimum & 0 & 0 & 0 & 0 & 0 & 0 & 0 & 0 \\
Maximum & 300 & 300 & 300 & 300 & 300 & 300 & 300 & 540 \\
Count & 182 & 182 & 181 & 180 & 183 & 181 & 184 & 187 \\
\hline
\end{tabular}

Table 6C: Number of Expected Hours of Dependent Enrollment, Over \$80,000

*Note: There are 24 blank responses.

\begin{tabular}{lrrrrrrrr}
\hline Academic Hour & & & & & & & & \\
Enrollment & $0 \%$ & $10 \%$ & $15 \%$ & $20 \%$ & $25 \%$ & $50 \%$ & $75 \%$ & $100 \%$ \\
\hline Over 1 Year & & & & & & & & \\
Mean & 2.622 & 2.326 & 2.326 & 2.619 & 2.628 & 4.023 & 6.814 & 11.756 \\
Standard & & & & & & & & \\
Deviation & 9.854 & 9.964 & 9.964 & 10.138 & 10.017 & 10.616 & 12.189 & 14.267 \\
Minimum & 0 & 0 & 0 & 0 & 0 & 0 & 0 & 0 \\
Maximum & 60 & 60 & 60 & 60 & 60 & 60 & 60 & 60 \\
Count & 45 & 43 & 43 & 42 & 43 & 43 & 43 & 45 \\
\hline Academic Hour & & & & & & & & \\
Enrollment & $0 \%$ & $10 \%$ & $15 \%$ & $20 \%$ & $25 \%$ & $50 \%$ & $75 \%$ & $100 \%$ \\
\hline Over 5 Years & & & & & & & & \\
Mean & 6.886 & 5.512 & 5.721 & 6.095 & 6.116 & 14.465 & 23.907 & 44.400 \\
Standard & & & & & & & & \\
Deviation & 21.222 & 20.674 & 20.641 & 20.861 & 20.623 & 29.928 & 34.220 & 49.265 \\
Minimum & 0 & 0 & 0 & 0 & 0 & 0 & 0 & 0 \\
Maximum & 100 & 100 & 100 & 100 & 100 & 120 & 120 & 160 \\
Count & 44 & 43 & 43 & 42 & 43 & 43 & 43 & 45 \\
\hline
\end{tabular}

The relationship between dependent tuition waiver and the expected hours for which dependents will enroll within next 1 year and 5 years is not linear. Figures 2, 3, and 4 provide 
evidence that there is an increase in expected number of hours of enrollment between a dependent tuition waiver rate of $25 \%$ and $50 \%$.

Figure 2: Expected Enrollment Hours over 5 Years by Discount Level for Faculty/Staff/Non-respondents

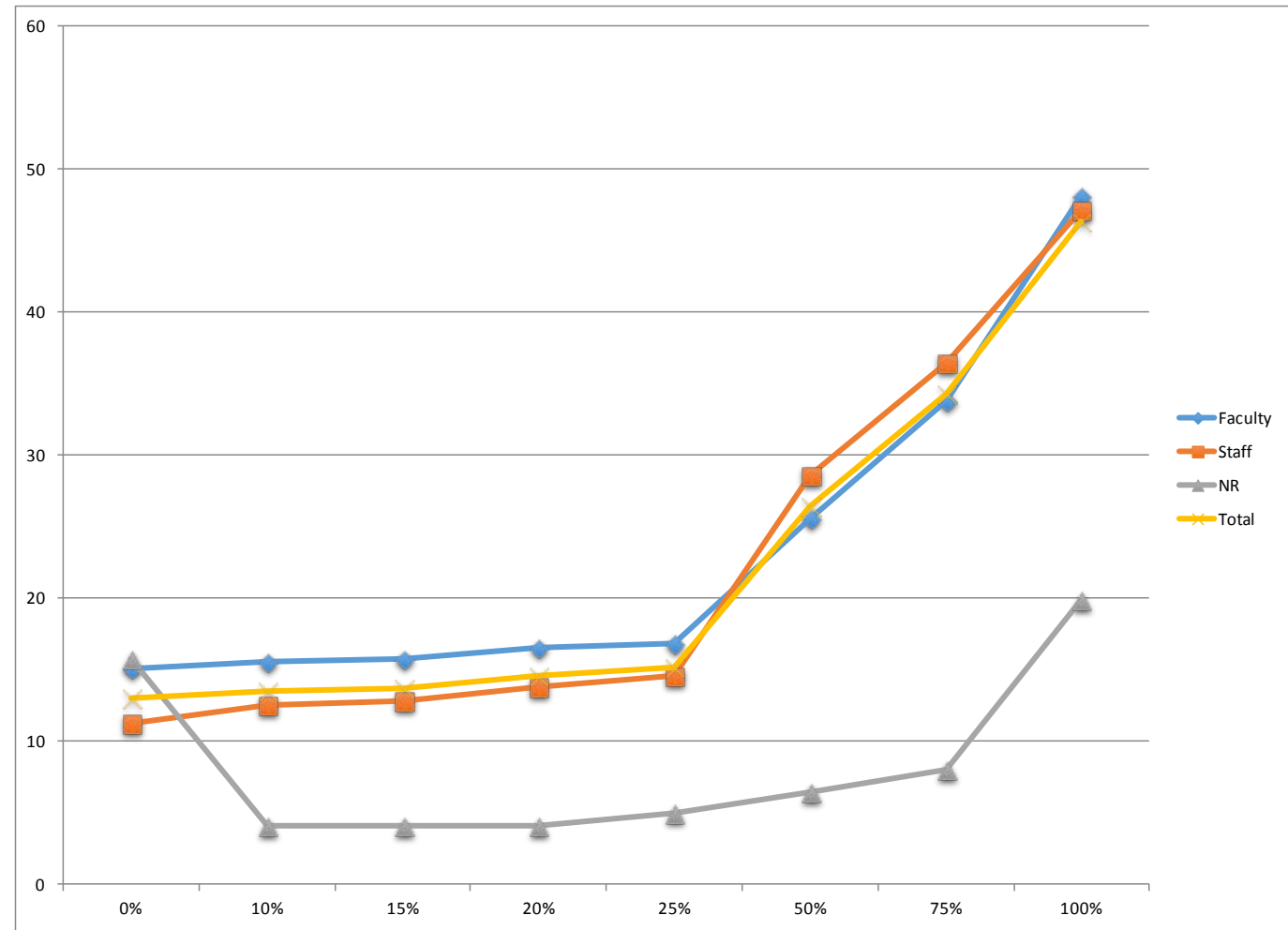


Figure 3: Expected Enrollment Hours for 5 Years by Discount Percent and Number of Dependents

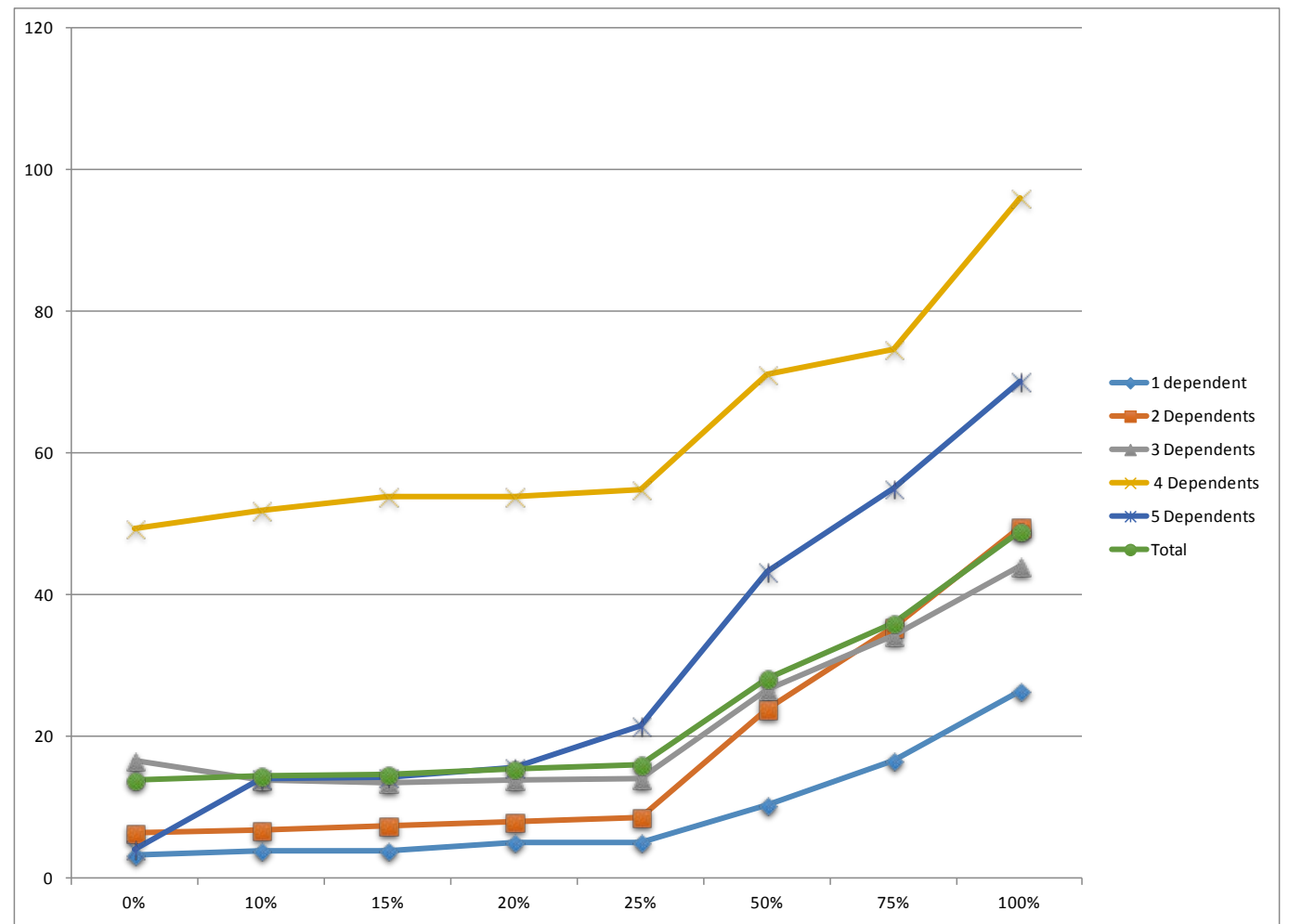


Figure 4: Expected Enrollment Hours over 5 Years against Discount Percent by Income Level

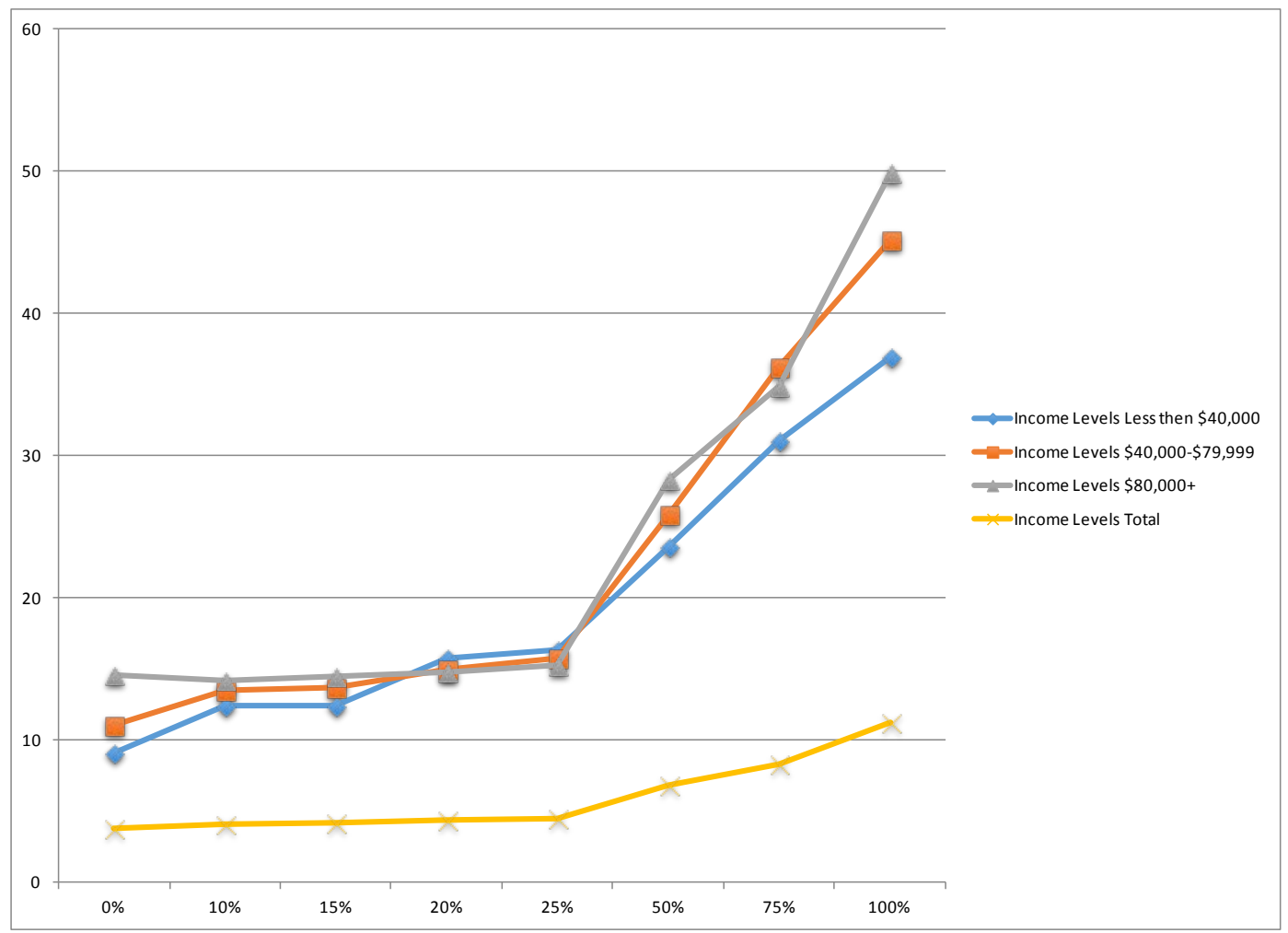

\section{2. What Will This Cost the University in Revenue (Before Offsetting Increased Productivity and Reduced Turnover)?}

At the institution under study where there is no dependent tuition waiver; employees’ dependents currently generate $\$ 1,210,043$ in tuition, fees and state contributions against a total institutional budget of $\$ 174,197,770$ in revenue. Increasing dependent tuition waivers from zero would have two offsetting effects: (a) increasing the average number of hours of enrollment and (b) decreasing the average amount charged per credit hour from its current amount of $\$ 248.98$ per credit hour for in-state undergraduates. Measuring the two offsetting factors, before additional increases in revenue from increased productivity and additional cost savings from reduced turnover, an increase from $0 \%$ (no dependent tuition waiver) to 10\% dependent tuition 
waiver would cost the university approximately $\$ 59,158$, or $0.03 \%$ of the total yearly budget. At a maximum, $100 \%$ dependent tuition and fee waiver, the cost to the university is estimated to be $0.69 \%$ of total budgeted revenues.

Table 7: Change in Revenue Projections for Different Dependent Tuition Waiver Rates (before Offsetting Productivity and Reduced Turnover)

Revenue Projections: 4 Hours Undergraduate 2013-2014 Rate $=\$ 995.92$

\begin{tabular}{|c|c|c|c|c|c|c|c|c|}
\hline & $0 \%$ & $10 \%$ & $15 \%$ & $20 \%$ & $25 \%$ & $50 \%$ & $75 \%$ & $100 \%$ \\
\hline $\begin{array}{l}\text { Revenue } \\
\text { (\$000’s) }\end{array}$ & 1,210 & 1,151 & 1,099 & 1,091 & 1,055 & 1,063 & 650 & - \\
\hline Differenc & & (59) & (111) & (119) & (155) & (147) & (559) & $(1,210)$ \\
\hline \multicolumn{9}{|c|}{ \% of 2013 Budgeted } \\
\hline
\end{tabular}

\section{Discussion}

This study examines what effects the employee benefit of reduced college tuition for dependents might have on employee retention and productivity at a public university in the U.S. and the net estimated cost of offering various levels of tuition reduction at that university. The hypothetical scenario presented to faculty and staff reduced tuition at varying rates: $10 \%, 15 \%$, 20\%, 25\%, 50\%, 75\%, and 100\%. In general, tuition waivers increased intent to work harder and intent to stay. Reduced tuition explained $17 \%$ of the variance in productivity and $28 \%$ in retention. Bryant and Allen (2013) found that when people are asked about why they left a job, pay was listed as the major or second major reason. However, out of 35 predictors, 
compensation ranks $27^{\text {th }}$. Bryant and Allen (2013) indicated the top three indicators as (a) the withdrawal process, especially turnover intentions and job searches (b) key job attitudes, and (c) the work environment. Consistent with Tillman (2013) and Bryant and Allen (2013), the results presented in Tables 2-5 suggest reduced tuition affects intended retention as well. In addition, the results presented in Tables 2-5 indicate that university employees, especially those with dependents, reported greater intended productivity and retention when dependent tuition waivers were available. While only intent was measured in this study, Ajzen (1991) linked intent to behavior. An increase in the amount of dependent tuition benefits results in employees who are willing to be more productive as well as remain with the institution. Although pay was not a top indicator of why people leave a university in earlier studies, it does relate to productivity and retention. Research Now (2012) concluded that people who leave jobs are likely to be physically and financially stressed out and feel their place of employment is not meeting their needs. In addition, that report concluded that salary plays an important role in a decision to leave an institution, although it is not the most important factor (Research Now, 2012).

Those with lower salaries placed a higher value on a reduced tuition plan. When employees were asked about dependent tuition waivers at various levels, at a $100 \%$ tuition waiver for their dependents, 20\% more of the respondents strongly agreed that they would work harder than with no tuition waiver. This study also provides evidence that as the percentage of tuition waivers increases, so does the probability of intent to stay employed at the university. From no tuition waiver to $100 \%$, the probability of choosing Strongly Agree for the Intent to Stay question increases by 40 percentage points.

According to Bozeman and Gaughan (2011), work context is an important factor of job satisfaction in colleges and universities. Any level of tuition waiver, combined with career 
support, recognition, working conditions, external relations, and role fit could prove beneficial to college and university performance. Mills, Matthews, Henning and Woo (2014) found that family-supportive perceptions of organizations influence administrative behavior, which in turn influences the subordinates' self-efficacy, affective organizational commitment and their perception of supervisor work effort. This effect held for all employees - even for employees without dependent care responsibilities.

These results indicate that the faculty/staff distinction is important for retention, but not productivity. This study design controlled for the faculty/staff distinction, but did not purse why faculty responses are different from those of staff. Most staff members are drawn from the local community, and a significant number of staff members have not earned (more than) a college degree. With most staff earning salaries that are lower than the salaries of faculty, they may be much more sensitive to changes in tuition costs for their children. In addition, they may be more likely to desire that their children attend college locally, which could mean more affordable housing, food and transportation costs. On the one hand, unless other organizations in the local community are hiring with offers of better salary/benefit packages, staff members who are unhappy with the current salary/benefits package may be more likely than faculty to continue to remain with the university. Faculty members, on the other hand, are hired through international searches and often have tenure. Faculty members who are earning relatively high salaries indicate that dependent tuition discounts for this institution do not affect their productivity or retention decisions. With these high salaries, they may already have sufficient college funds for their own children, and/or they may believe their salaries are so high because they themselves attended institutions which they hold in higher esteem, outside of this community. Other faculty, who may or may not be sensitive to dependent tuition benefits, may not be originally from the 
local community and may feel constrained to remaining in the local community; they are much more likely to engage in job search, rather than reductions in productivity. Faculty who do feel constrained to the local community may respond to unhappiness with compensation through lower productivity. This group would include faculty (a) close to retirement, (b) who do not believe their skill set would lead to tenure elsewhere, or (c) with spouses whose income exceeds that of the faculty member, if the spouse's income and/or career would be negatively affected by a move.

In this study, university employees were presented with options for various tuition waiver rates. The long term affects are not actually known, however, it is possible that employees were enticed, long term, by the idea of a tuition waiver. Gibbons et al. (1998) found that when certain circumstances encourage particular behavior, preconceived ideas do not relate to behavior but openness to opportunity. Thus the results of this study can be viewed in light of the potential for future behaviors predicated on the idea of opportunity. However, willingness may not improve predictive behavior (Matterne et al., 2011). Therein lies a potential predicament: it appears that offering dependent tuition assistance will increase employee productivity and retention, but this cannot be proven without actually committing to offer assistance, at least on a limited basis. And, before making such an offer, responsible administration should have an estimate of the net cost to the institution. The direct net cost to the institution is the opportunity cost of foregone tuition and fees revenue plus any matching state funds. Since projected increases in enrollment are small relative to the size of the university, no additional faculty or facilities costs would be needed to pilot a dependent tuition assistance program or to offer one permanently at this level of operations. These costs are small-less than $1 \%$ of total projected revenues for the institutionindicating that there is little financial risk to the university for piloting such a program. Even the 
small risk of offering assistance can be further controlled by offering some limited version of dependent tuition assistance, such as offering assistance to lower paid faculty and staff first, measuring the effect of that offer, then expanding the assistance to higher paid faculty and staff as appropriate. Alternatively, administration could offer assistance up to a limited number of dependents per family. In that way, direct net costs could be lessened.

One limitation of this study is that direct net costs were measured, but indirect net costs were not. Additional indirect revenues from book and supply sales, trademarked logo sales, paid athletic and program attendance, campus vendor sales and future alumni donations are not quantified in this study, but would reduce the net cost further, and perhaps produce net long-term incremental revenue.

The faculty/staff distinction is important for retention, but not productivity. Why? Tenure? More opportunity for local staff job substitution? What is the significance of income? Can high earners afford college anywhere (cost is not an issue) v. low earners are more price sensitive? Does being local matter (dependents could still live at home) in cost analysis, and if so, how?

\section{1. Unanswered Questions for Future Research}

Higher education is faced with leading and managing with a societal shift focused on economic outcomes as its main priority (Saunders, 2010). Yet, recruitment and retention of college and university employees include total rewards (ASHE, 2012). Do past behavior indicators of planned theory, suggesting the frequency of past behavior strengthens current attitude, affect employee choices to the extent that improved benefits have a lesser effect?

Should an institution provide employment advantages through robust benefits (Tillman, 2013), 
such as tuition waivers based on data that may only provide short term answers to productivity and long term employment, or should it risk turnover rates costing institutions upwards of 20\% of that employee’s annual salary (Boushey \& Glynn, 2012)? There are no easy answers. Nevertheless, in an environment in which economic indicators are the mark of success or failure (Berry \& Worthen, 2012), and individuals are encouraged to pursue their own economic advantages (Fredman \& Doughney, 2012), can higher education not afford to offer its employees robust benefits, especially when the marginal costs of those benefits is low?

\section{Conclusion}

This study examines whether a hypothetical tuition waiver at eight levels (in the range of 0\% to $100 \%$ ) significantly affects employees’ intentions to work harder and stay at a public university in the U.S., controlling for number of dependents, annual salary, gender, faculty/staff status, age and experience.

The results indicate that for higher-education institutions where faculty/staff retention and productivity are a priority, maximizing or offering dependent college tuition waiver may be a relatively low-cost benefit to increase intended retention and productivity. The higher education industry has the opportunity to offer reduced tuition to the dependents of its employees, which would save employees’ families substantial resources at very little additional cost to the institution. Some, generally private, colleges and universities have recognized that opportunity and have historically provided dependent college tuition waivers for their employees. Such benefits are rarer in public institutions, where, until recently, tuition has been much more affordable. 
The results suggest that the amount of the tuition waiver, number of dependents and annual salary were all significant predictors of intended increased productivity and Intent to Stay employed at the current institution. Additionally, faculty or staff classification was also significant for the Intent to Stay at the current institution. The expected increases in dependent enrollment hours over both one year and five years were examined and the increase curve was found to be nonlinear, with the slope increasing at a higher rate once the tuition waiver reaches 25\%. The estimated direct opportunity cost (reduction in revenue) as a percent of total budgeted revenue was less than $1 \%$ of total budgeted revenue in all cases, and generally less than 1/10 of $1 \%$ for dependent tuition waivers of $50 \%$ or less.

The major conclusion of interest to institutions where faculty retention or staff retention and productivity are a priority is that maximizing or introducing a new dependent college tuition waiver may be a relatively low-cost benefit to increase intended retention and productivity. Results from this paper allow administrators to weigh the costs and benefits to make wellreasoned, informed decisions of the effects of adopting or expanding a dependent tuition reimbursement policy. Because a tuition waiver is a family-friendly policy, gains could be made among faculty generally, but may be particularly impactful among women in STEMM disciplines. Society as a whole can benefit as universities retain and motivate key faculty and staff, which can reasonably be expected to increase service levels to students.

\section{References}

Ajzen, I. (1991). The theory of planned behavior. Organizational Behavior and Human Decision Processes, 50(2), 179-211.

Azjen, I. (2002). Residual effects of past behavior: Habituation and reasoned action perspectives. Personality and Social Psychology, 6, 107-122. 
Ajzen, I. (2011). Job satisfaction, effort, and performance: A reasoned action perspective. Contemporary Economics, 5(4),32-43.

Altbach, P. G. (2011). Harsh realities: The professoriate in the twenty-first century. In P. G. Altbach, P. J. Gumport, \& R. O. Berdahl (Eds.), American Higher Education in the Twenty-first Century: Social, Political, and Economic Challenges ( ${ }^{\text {rd }}$ ed., pp. 227-253). Baltimore: Johns Hopkins University Press.

Anderson, D. M., Morgan, B.L. \& Wilson, J.B. (2002). Perceptions of Family-Friendly Policies: University versus Corporate Employees. Journal of Family and Economic Issues, 23(1), 73-92.

Armitage, C. J., \& Conner, M. (2001). Efficacy of the theory of planned behavior: A metaanalytical approach. British Journal of Social Psychology, 40, 471-499.

Berry, J., \& Worthen, H. (2012). Higher education as a workplace. Dollars \& Sense, (303), 1923.

Boushey, H. \& Glynn, S.J. (2012). There are significant business costs to replacing employees. Center for American Progress. November 16, 2012.

Bozeman, B., and Gaughan, M. (2011). Job satisfaction among university faculty: Individual, work, and institutional determinants. Journal of Higher Education, 82(2), 154-186.

Bryant, P. C., \& Allen, D. G. (2013). Compensation, benefits and employee turnover: HR strategies for retaining top talent. Compensation \& Benefits Review, 45(3), 171-175.

Cook, R., \& French, D. P. (2011). The role of context and timeframe in moderating relationships within the theory of planned behavior. Psychology and Health, 26, 1225-1240.

Dur, U. M. \& Ünver, M. U. (2012).Tuition exchange. No. 815. Boston College Department of Economics. 
Finkelstein, M. J. (2001). Understanding the American academic profession. In P. G. Altbach, P. J. Gumport, \& D. B. Johnstone (Eds.), In Defense of American Higher Education (pp. 323.3-51). Baltimore: Johns Hopkins University Press.

Fischer, K. (May 15, 2011). Crisis confidence threatens colleges: Rising costs test families' faith, while 1 in 3 presidents see academe on the wrong road. The Chronicle of Higher Education.

Flaherty, C. N. (2007).The effect of tuition reimbursement on turnover: A case study analysis. NBER Working Paper No. 12975. Issued in March 2007.

Fredman, N., \& Doughney, J. (2012). Academic dissatisfaction, managerial change and neoliberalism. Higher Education, 64(1), 41-58.

Freedman, J.L. \& Fraser, S.C. (1966). Compliance without pressure: The foot-in-the-door technique. Journal of Personality and Social Psychology, 4, 195-202.

Friedenthal, J. H., Bartha, R., Webber, R.P., Lancaster, R.V., Weil, R.L. \& Wilbanks, J.J. (1973). Tuition remission and the faculty child: A reconsideration. AAUP Bulletin, 59(3), 327-333.

Galinsky, E., Bond, J.T. \& Friedman, D.E. (1996).The role of employees in addressing the needs of employed parents. Journal of Social Issues, 52(3), 111-136.

Gibbons, E. X., Gerrard, M., Ouelette, J., \& Burzette, B. (1998). Cognitive antecedents to adolescent health risk: Discriminating between behavioral intention and behavioral willingness. Psychology and Health, 13, 319-340.

Greene, W.H. (2003). Econometric Analysis. $5^{\text {th }}$ ed. Upper Saddle River, NJ: Prentice-Hall. Hermsen, J., \& Rosser, V. (2008). Examining work engagement and job satisfaction of staff members in higher education. CUPA-HR Journal, 59(2), 10-18. 
Howard-Baldwin, T., Celik, B., Kraska, M. (2012). Administrator job satisfaction in higher education. ERIC submission (ED531811).

Jacobs, J. A., \& Winslow, S. E. (2004). Overworked faculty: Job stresses and family demands. The Annals of the American Academy of Political and Social Sciences, 596(1), 104-129.

Lemke, T. (2001). The birth of bio-politics: Michel Foucault's lecture at the College de France on neo-liberal governmentality. Economy and Society, 30(2), 190-207.

Levin, J. S. (2005). The business culture of the community college: Students as consumers; students as commodities. New Directions for Higher Education, 129, 11- 26.

Manchester, C. F. (2012). General human capital and employee mobility: How tuition reimbursement increases retention through sorting and participation. Industrial \& Labor Relations Review, 65(4), 951-974.

Matterne, U., Diepgen, T. L., \& Weisshaar, E. (2011). A longitudinal application of three behaviour models in the context of skin protection behaviour in individuals with occupational skin disease. Psychology and Health, 26, 1188-1207

Meyerhoff, E., Johnson, E., \& Braun, B. (2011). Time and the university. ACME: An International E-Journal for Critical Geographies, 10(3), 483-507.

Mills, M. J., Matthews, R. A., Henning, J. B., \& Woo, V. A. (2014). Family-supportive organizations and supervisors: how do they influence employee outcomes and for whom? The International Journal of Human Resource Management, 25(12), 1763-1785.

Moors, A.C., Malley, J.E., \& Stewart, A.J. (2014). My Family Matters: Gender and Perceived Support for Family Commitments and Satisfaction in Academia Among Postdocs and Faculty in STEMM and Non-STEMM Fields. Psychology of Women Quarterly, 0361684314542343. 
Norman, P., \& Cooper, Y. (2011). Theory of planned behavior and breast self-examination: Assessing the impact of past behaviour, context stability and habit strength. Psychology and Health, 26, 1156-1172.

Pattie, M., Benson, G.S. \& Baruch, Y. (2006)Tuition reimbursement, perceived organizational support, and turnover intention among graduate business school students. Human Resource Development Quarterly, 17(4), 423-442.

Plehwe, D., Walpen, B. J., \& Neunhöffer, G. (Eds.). (2007). Neoliberal hegemony: a global critique. Routledge.

Power, R. (2013). Leader-member exchange theory in higher and distance education. International Review of Research in Open \& Distance Learning, 14(4), 277-283.

Research Now. (2012). Aflac WorkForces sponsored report.

Saunders, D. B. (2010). Neoliberal ideology and public higher education in the United States. Journal for Critical Education Policy Studies, 8(1), 41-77.

Slaper, T. F., \& Foston, A. K. (2013). Onward and upward with the cost of college. Indiana Business Review, 88(2), 3-9.

Radice, H. (2013). How we got here: UK higher education under neoliberalism. ACME: An International E-Journal for Critical Geographies, 12(3), 407-418.

Strategic HR and talent management in higher education. (2012). ASHE Higher Education Report, 38(1), 45-67.

Tillman, A. (2013). Improving worker satisfaction yields improved worker-retention rates. Employment Relations Today (Wiley), 39(4), 27-31.

Turner, R. S. (2008). Neo-liberal ideology: History, concepts and policies. Oxford University Press. 
Tuition Exchange (2014). http://www.tuitionexchange.org/

Zhang, L., \& Liu, X. (2010). Faculty employment at 4-year colleges and universities. Economics of Education Review, 29(4), 543-552. 